\title{
Reality and Future of Rechargeable Lithium Batteries
}

\author{
Haisheng Tao, Zhizhong Feng, Hao Liu, Xianwen Kan and P. Chen* \\ Department of Chemical Engineering, University of Waterloo, 200 University Avenue West, Waterloo, Ontario, N2L \\ $3 G 1$, Canada
}

\begin{abstract}
Compared to other types of rechargeable batteries, the rechargeable lithium battery has many advantages, such as: higher energy density, lower self-discharge rate, higher voltages and longer cycle life. This article provides an overview of the cathode, anode, electrolyte and separator materials used in rechargeable lithium batteries. The advantages and challenges of various materials used in rechargeable lithium batteries will be discussed, followed by a highlight of developing trends in lithium battery research.
\end{abstract}

Keywords: Rechargeable lithium battery, cathode, anode, electrolyte, separator, review.

\section{INTRODUCTION}

Energy and environment are the two most challenging issues faced by our society. With the production of oil predicted to decline and the number of vehicles and their pollution impact to increase globally, a safe, low-cost, highefficiency and environmentally friendly alternative power sources have become a most urgent need. Solar energy, $\mathrm{H}_{2}$ energy, fuel cells and batteries are attracting considerable interest as alternative power sources. Specifically, batteries are portable and easily replaced, commonly used in household and industrial applications such as energy storage and management [1]. Among various existing batteries (Fig. 1), lithium batteries have raised the most interest and have a high priority on the development of energy projects in many countries because of their high energy density, long cycle life, cost-effective, long lasting, and abuse-tolerant properties [2].

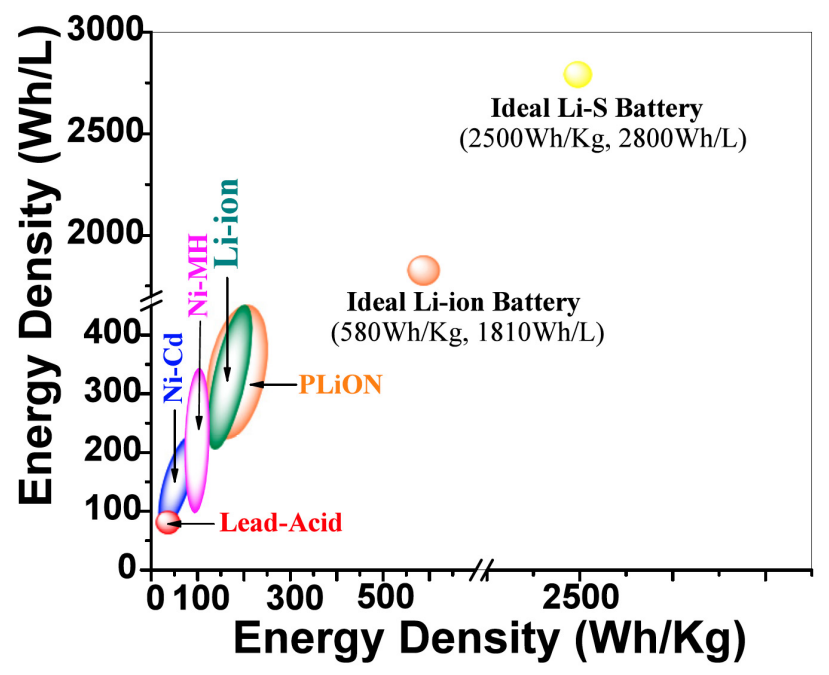

Fig. (1). The energy density of different batteries.

*Address correspondence to this author at the Department of Chemical Engineering, University of Waterloo, 200 University Avenue West, Waterloo, Ontario, N2L 3G1, Canada; Tel: (519) 888-4567x35586; Fax: (519) 746-4979; E-mail: p4chen@uwaterloo.ca
Rechargeable lithium battery is of present interest. There are many kinds of rechargeable lithium batteries. They have different classifications according to the forms of lithium (e.g. lithium metal as anode directly, we call it lithium battery. For lithium trans-metal salt as anode, we call it lithium ion battery. Usually, we simply call them lithium battery). Based on the types of electrolytes (such as lithiumaqueous battery, lithium-organic battery), and the kinds of cathodes (such as lithium cobalt oxide battery, lithium nickel oxide battery, lithium manganese oxide battery, lithium iron phosphate battery, sulfur battery), we have several other classifications as well.

However, each battery composes of one or several cells, and each cell has its own characteristic cell potential (V), capacity $\left(\mathrm{Ah} \mathrm{kg}^{-1}\right.$ or $\mathrm{Ah} \mathrm{L}^{-1}$ ), and energy density ( $\mathrm{Wh} \mathrm{kg}^{-1}$ or Wh $\left.\mathrm{L}^{-1}\right)$. These characteristics are determined by the chemical properties of each component of the cell. To provide the required voltage and capacity, the cells can be connected in series or parallel configuration. Three primary functional components of an individual cell are the anode (negative electrode), the cathode (positive electrode), and the electrolyte. The transfer of $\mathrm{Li}$ ions between the two electrodes is facilitated by the dissociated lithium salts in the electrolyte. To fabricate a complete cell, however, requires additional components, such as a separator, current collector, tab and cell can.

In the case of discharge, the transfer of energy and current of a rechargeable lithium battery occurs when the electrodes are connected externally to a load (Fig. 2). Li ions are liberated from the anode, pass through the separator, and are "inserted" into the cathode. At the same time, the anode releases electrons, which pass through the external circuit and then arrive at the cathode. In the case of charge, the process is reversed. The cycling of a battery depends not only on the property of individual components: cathode, anode, electrolyte and separator, but also on the compatibility among different components. During the development of rechargeable lithium batteries, the first breakthrough was the discovery of $\mathrm{Li}$ ion intercalation compounds that enable reversible $\mathrm{Li}$ ion intercalation/deintercalation, which opened the concept of 
rechargeability. A second breakthrough was the application of nanostructured materials, which continuously improve the performance of rechargeable lithium batteries [3]. Nanostructured materials can increase the specific surface area as well as reduce diffusion length for electronic and $\mathrm{Li}$ ion transport, leading to a high charge/discharge rate.

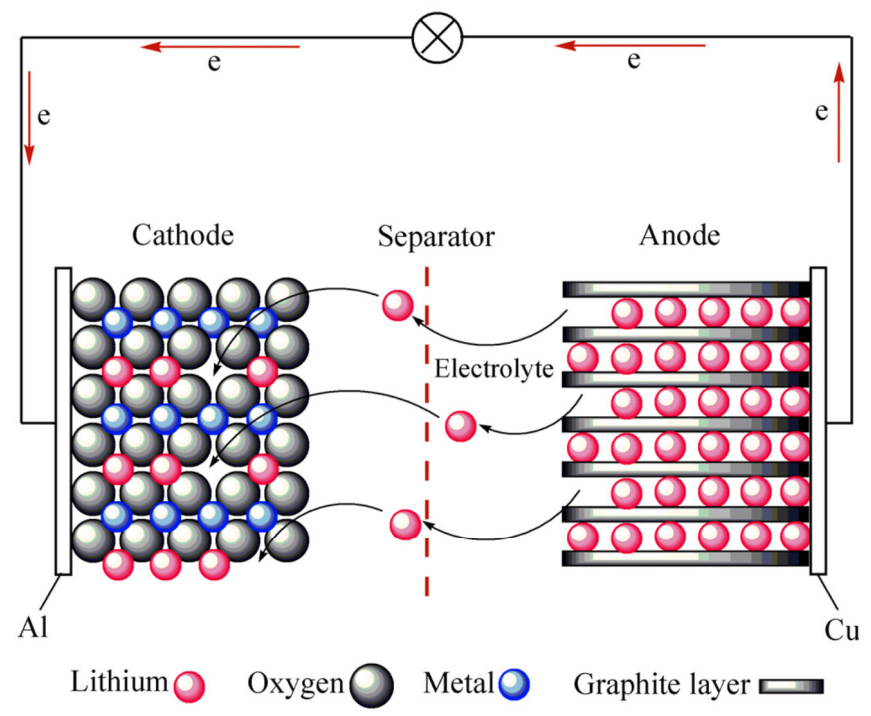

Fig. (2). Schematic illustration of a lithium battery (in the case of discharge).

As one of the great successes of modern electrochemistry, the lithium battery has played a key role in the consumer electronic market. Thanks to the improvement of the electrodes and electrolytes, the lithium battery is moving to dominate not only portable battery industry (MP3 player, laptop, cell phone and camera etc.), but also electronic automotive transportation (electric vehicles, full hybrid electric and plug-in electric vehicles). But the reality is complex: although scientists have produced numerous potential battery chemistries, problems of various natures still prevent the large scale application of lithium batteries for the electronic automotive transportation. None of them perform well on all the crucial factors of cost, safety, durability, power and capacity [4]. To further advance in the science and technology of lithium batteries, new strategies must be implemented. This includes modifications of the electrode and electrolyte components and further improvements in their safety, environmental sustainability and energy content.

The following sections provide a review of rechargeable lithium batteries in terms of cathode, anode, electrolyte and separator. Significant changes to the properties and performance of these battery components brought by the development of intercalation and nanostructured materials are demonstrated. The challenges and potentials of rechargeable lithium batteries are also discussed.

\section{CATHODES}

The material for an ideal cathode of a rechargeable lithium battery should have following properties: First, the material may be capable of reversibly intercalating/deintercalating $\mathrm{Li}$ ions at a large capacity and high potential. Second, the material should undergo minimal structural change during Li ion intercalation/ deintercalation, as required for good cycle performance. Third, the material should suffer minimal redox potential change during $\mathrm{Li}$ ion intercalation/deintercalation, as required for smooth charge/discharge curves. Fourth, the material should have high electronic conductivity, high $\mathrm{Li}$ ion diffusion rate and conductivity, as required for high charge/discharge rate. Lastly, the material should be chemically stable with the electrolyte under operating potentials.

The intensively studied cathode materials mainly include lithium cobalt oxide, lithium nickel oxide, lithium manganese oxide, and olivine phases, in particular, lithium iron phosphate $\left(\mathrm{LiFeO}_{4}\right)$. Additionally, sulfur based cathode materials have attracted significant attention recently, because of their high specific capacity $\left(1670 \mathrm{Ah} \mathrm{Kg}^{-1}\right)$. For lithium cobalt oxide and lithium nickel oxide, both of them contained layered structure which could offer highly accessible ion diffusion pathways. The benefit in using lithium iron phosphate is that, in addition to being naturally abundant and inexpensive, they are less toxic than cobalt, manganese, and nickel compounds. There are many merits making sulfur as a very suitable cathode material, such as the low equivalent weight, low cost, high capacity, and environmental friendliness. The advantages and disadvantages of different cathode materials are discussed below.

\subsection{Lithium Cobalt Oxide and Lithium Nickel Oxide}

Lithium cobalt oxide $\left(\mathrm{LiCoO}_{2}\right)$ is an intercalation material allowing reversible intercalation/deintercalation of $\mathrm{Li}$ ion. $\mathrm{LiCoO}_{2}$ has a large tap density $\left(2.8 \sim 3.0 \mathrm{~g} \mathrm{~cm}^{-3}\right)$, large gravimetric capacity $\left(\sim 140 \mathrm{Ah} \mathrm{Kg}^{-1}\right)$, excellent cyclability (500 800 cycles), and high operating voltage (3.6 V). These desirable qualities make $\mathrm{LiCoO}_{2}$ a widely used cathode material in commercial batteries. However, when the cell is over-charged or over-discharged, the instability of $\mathrm{LiCoO}_{2}$ structure could lead to severe material degradation and even explosion of the cells. This raises serious operation concerns for commercial operation, but even more so for personal batteries. Additionally, cobalt is a relatively rare and expensive metal, which limits the widespread implementation of $\mathrm{LiCoO}_{2}$ in power batteries for electric vehicles.

Besides $\mathrm{LiCoO}_{2}$, there are several other well-known $\mathrm{Li}$ ion intercalation compounds. Lithium nickel oxide $\left(\mathrm{LiNiO}_{2}\right)$ is considered a preferred cathode material for its larger gravimetric capacity $\left(275 \mathrm{Ah} \mathrm{Kg}^{-1}\right)$, higher natural abundance and lower toxicity as compared with $\mathrm{LiCoO}_{2}$. But, the structure of $\mathrm{LiNiO}_{2}$ is not as stable as that of $\mathrm{LiCoO}_{2}$ [58]. To mitigate the structural instability, partial substitution of $\mathrm{Ni}$ with $\mathrm{Al}, \mathrm{Ga}, \mathrm{Mg}$ or $\mathrm{Ti}$ is considered. For example, $\mathrm{LiNi}_{0.75} \mathrm{Al}_{0.25} \mathrm{O}_{2}$ has shown higher thermal stability and safer operation during over-charge. Moreover, a novel layered material of $\mathrm{LiNi}_{0.32} \mathrm{Mn}_{0.33} \mathrm{Co}_{0.33} \mathrm{Al}_{0.01} \mathrm{O}_{2}$ with $\alpha-\mathrm{NaFeO}_{2}$ structure synthesized by sol-gel method has been used as a cathode in lithium batteries. The capacity retention of $\mathrm{LiNi}_{0.32} \mathrm{Mn}_{0.33} \mathrm{Co}_{0.33} \mathrm{Al}_{0.01} \mathrm{O}_{2}$ has been improved to $97 \%$ [9]. Another problem with $\mathrm{LiNiO}_{2}$ is the capacity fading [10], which may be solved by partially substituting $\mathrm{Ni}$ with $\mathrm{Ti}$ and Mg. A typical example is $\mathrm{LiNi}_{1-\mathrm{x}} \mathrm{Ti}_{\mathrm{x} / 2} \mathrm{Mg}_{\mathrm{x} / 2} \mathrm{O}_{2}$, which has been used as a cathode material at a high capacity of $180 \mathrm{Ah}$ $\mathrm{Kg}^{-1}$ and good thermal stability [11]. 
The high capacity of Ni-rich $\mathrm{Li}\left[\mathrm{Ni}_{1-\mathrm{x}} \mathrm{M}_{\mathrm{x}}\right] \mathrm{O}_{2}(\mathrm{M}=\mathrm{Co}, \mathrm{Mn})$ is very attractive, if the structural instability and thermal properties are improved. Yang-Kook Sun et al. synthesized a spherical core-shell structure with a high capacity (from the $\mathrm{Li}\left[\mathrm{Ni}_{0.8} \mathrm{Co}_{0.1} \mathrm{Mn}_{0.1}\right] \mathrm{O}_{2}$ core) and a good thermal stability (from the $\mathrm{Li}\left[\mathrm{Ni}_{0.5} \mathrm{Mn}_{0.5}\right] \mathrm{O}_{2}$ shell) [12]. This core-shell structured $\mathrm{Li}\left[\left(\mathrm{Ni}_{0.8} \mathrm{Co}_{0.1} \mathrm{Mn}_{0.1}\right)_{0.8}\left(\mathrm{Ni}_{0.5} \mathrm{Mn}_{0.5}\right)_{0.2}\right] \mathrm{O}_{2} /$ carbon cell has a superior cyclability and thermal stability relative to the $\mathrm{Li}\left[\mathrm{Ni}_{0.8} \mathrm{Co}_{0.1} \mathrm{Mn}_{0.1}\right] \mathrm{O}_{2}$ at the $1 \mathrm{C}$ rate for 500 cycles. Expanding on this idea, a concentration-gradient cathode material for rechargeable lithium batteries based on a layered lithium nickel cobalt manganese oxide was developed [13]. This novel high-capacity and safe cathode material with an average composition of $\mathrm{Li}\left[\mathrm{Ni}_{0.68} \mathrm{Co}_{0.18} \mathrm{Mn}_{0.18}\right] \mathrm{O}_{2}$, in which each particle consists of bulk material $\mathrm{Li}\left[\mathrm{Ni}_{0.8} \mathrm{Co}_{0.1} \mathrm{Mn}_{0.1}\right] \mathrm{O}_{2}$ coated by a concentration-gradient outer layer which the reactive nickel ions are gradually substituted by manganese ions. As expected, this concentration-gradient cathode material achieved a high capacity of $209 \mathrm{Ah} \mathrm{Kg}^{-1}$ and also showed superior thermal stability.

\subsection{Lithium Manganese Oxides}

Lithium manganese oxides yield a high operating voltage $(3.7 \mathrm{~V})$ and are favored over $\mathrm{LiCoO}_{2}$ and $\mathrm{LiNiO}_{2}$ in electric vehicles because they are safe, cheap and non-toxic. There are two well known "lithium-rich" manganese oxides, the spinel $\mathrm{LiMn}_{2} \mathrm{O}_{4}$ [14-17] and orthorhombic $\mathrm{LiMnO}_{2}$ [18]. Unfortunately, the capacity of these materials decreases rapidly during cycling at normal operating temperatures due to structural instability, but this problem can be solved through cationic substitution with $\mathrm{Cr}, \mathrm{Al}, \mathrm{Mg}$, and $\mathrm{Fe}[15$, 19-23]. It was reported that Al-doped $\mathrm{LiAl}_{0.1} \mathrm{Mn}_{1.9} \mathrm{O}_{4}$ materials using a room-temperature solid-state grinding reaction followed by calcination showed the obviously improved cyclability compared with the pristine $\mathrm{LiMn}_{2} \mathrm{O}_{4}$ [24]. Another problem is its limited cycling and storage performance at elevated temperatures $\left(>40^{\circ} \mathrm{C}\right)$, which can be improved by changing the structure (such as using synthesizing bi-substituted $\mathrm{LiMn}_{2-\mathrm{x}} \mathrm{Al}_{\mathrm{x}} \mathrm{O}_{4-\mathrm{z}} \mathrm{F}_{\mathrm{z}}$ ) [25, 26], or modifying the surface (such as acetylacetone, boron oxide and alkali-hydroxydes solution treatment) [27, 28].

\subsection{Lithium Iron Phosphate}

In 1996, lithium iron phosphate $\left(\mathrm{LiFePO}_{4}\right)$ was discovered and used as a cathode material for rechargeable lithium batteries [29, 30]. It gained vehicle market acceptance because of its low cost, low toxicity, excellent thermal stability, and high gravimetric capacity (170 Ah $\mathrm{Kg}^{-1}$ ). However, the main application barrier of $\mathrm{LiFePO}_{4}$ was its intrinsically low electrical conductivity [31]. This may be overcome by synthesizing $\mathrm{LiFePO}_{4}$ in nanoparticles. Alternatively, the same improvement in electrical conductivity can be achieved by carbon coating of $\mathrm{LiFePO}_{4}$ [32-34] or doping $\mathrm{LiFePO}_{4}$ with various metal elements [3537]. It was reported that stoichiometric $\mathrm{Cu}$-doped lithium ion phosphate $\mathrm{LiFe}_{1-\mathrm{x}} \mathrm{Cu}_{\mathrm{x}} \mathrm{PO}_{4} / \mathrm{C}(\mathrm{x}=0,0.01,0.015,0.02,0.025)$ cathode materials had been synthesized by a solid state high temperature reaction in an inert atmosphere using $\mathrm{Cu}(\mathrm{Ac})_{2}$ as a dopant and $\mathrm{FePO}_{4}$ as a precursor. The charge/discharge test showed that the cathode materials possessed the excellent charge/discharge capacities, about $150 \mathrm{Ah} \mathrm{Kg}^{-1}$ and $297 \mathrm{Ah}$ $\mathrm{L}^{-1}$ at a rate of $0.1 \mathrm{C}$ and more than $127 \mathrm{Ah} \mathrm{Kg}^{-1}$ and $252 \mathrm{Ah}$ $\mathrm{L}^{-1}$ at a rate of $2 \mathrm{C}$ [38]. These approaches do not increase the lattice electronic conductivity or chemical diffusion coefficient of lithium within the crystal.

The power density (i.e., the charge/discharge rate) of $\mathrm{LiFePO}_{4}$ is limited by the rate of $\mathrm{Li}$ ion and electron migration through the electrolyte into the electrode [39]. Strategies to increase the charge/discharge rate of $\mathrm{LiFePO}_{4}$ have focused on improving electron transport overall [35] or simply at the cathode surface $[31,40]$, along with reducing the diffusion distance by using nano-sized materials [41, 42]. Moreover, $\mathrm{LiFePO}_{4}$ nanoparticals coated with a lithium phosphate layer demonstrated an extremely high charge/discharge rate [43] due to the lithium phosphate outer layer providing an ultrafast charging and discharging $\mathrm{Li}$ ion tunnel. Another promising cathode material is $\mathrm{LiFeSO}_{4} \mathrm{~F}$ [44]. By introducing fluorine and by replacing phosphate group with more electron-withdrawing sulphate groups, this material does not need nanostructuring or carbon coating.

\subsection{Sulfur-Based Materials}

The specific capacity of sulfur (S) cathodes is high (1670 $\mathrm{Ah} \mathrm{Kg}^{-1}$ ) compared to that of most other materials, e.g., $\mathrm{LiCoO}_{2}, \mathrm{LiNiO}_{2}, \mathrm{LiMn}_{2} \mathrm{O}_{4}, \mathrm{LiMnO}_{2}$ and $\mathrm{LiFePO}_{4}$. In addition, $\mathrm{S}$ has a low cost and readily available, having a wide operation temperature range and possibility of long cycling. However, it has not been widely commercialized because of the poor electrical conductivity of elemental S and polysulfide shuttling that occurs during charge/discharge cycles [45]. To solve these problems as well as large volume change of S, a nanostructured S-carbon [46] and a hierarchically structured S-carbon nanocomposite [47] were developed for cathodes.

Lithium sulfide $\left(\mathrm{Li}_{2} \mathrm{~S}\right)$ is also a possible cathode material. Similar to $\mathrm{S}$, the poor electronic conductivity of $\mathrm{Li}_{2} \mathrm{~S}$ restricts its practical application, despite a high theoretical capacity of $1166 \mathrm{Ah} \mathrm{Kg}^{-1}[48,49]$. Metal additives (such as $\mathrm{Cu}, \mathrm{Co}$, and $\mathrm{Fe}$ ) have been employed to enhance the conductivity of $\mathrm{Li}_{2} \mathrm{~S}-$ based cathodes [48-50]. But the metal additives result in a lower output voltage $[49,50]$. A nanostructured $\mathrm{Li}_{2} \mathrm{~S}$-carbon [47] has been employed as a cathode material to solve the insulation and solubility of polysulphide anions during charge/discharge [51].

Both S-carbon and $\mathrm{Li}_{2} \mathrm{~S}$-carbon nanostructured materials use electrical conductive micro/mesoporous carbon for loading $\mathrm{S}$ or $\mathrm{Li}_{2} \mathrm{~S}$. These materials have a high specific surface area in contact with electrolytes as well as a reduced diffusion length for electronic and $\mathrm{Li}$ ion transport. These properties lead to a high charge/discharge rate. Furthermore, the spatial confinement of micro/mesoporous carbon represses the solubility of polysulphide anions.

There are a number of commercial cathode materials available. However few of them can meet all the necessary requirements. Considering of these, ternary materials [Such as $\left.\mathrm{LiCo}_{\mathrm{x}} \mathrm{Mn}_{\mathrm{y}} \mathrm{Ni}_{1-\mathrm{x}-\mathrm{y}} \mathrm{O}_{2}(0<\mathrm{x}<0.5,0<\mathrm{y}<0.5)\right]$ and sulfur are the possible cathodes to be commercialized. Table 1 summarizes the properties of commonly used materials in rechargeable lithium batteries. 
Table 1. Comparison of Typical Cathode Materials

\begin{tabular}{|c|c|c|c|}
\hline & $\mathrm{LiCoO}_{2}$ & $\operatorname{LiMn}_{2} \mathbf{O}_{4}$ & $\mathrm{LiFePO}_{4}$ \\
\hline Theoretical Capacity $\left(\mathrm{Ah} \mathrm{Kg}^{-1}\right)$ & 145 & 148 & 170 \\
\hline Commercial Capacity $\left(\mathrm{Ah} \mathrm{Kg}^{-1}\right)$ & $135 \sim 140$ & $100 \sim 110$ & $140 \sim 160$ \\
\hline Tap Density $\left(\mathrm{Kg} \mathrm{L}^{-1}\right)$ & $2.6 \sim 3.0$ & $1.8 \sim 2.4$ & $0.8 \sim 1.4$ \\
\hline Discharge Plateau (V) & 3.6 & 3.7 & 3.3 \\
\hline Cycle Life (Cycles) & $500-800$ & $1000-1500$ & $>3000$ \\
\hline Working Temperature $\left({ }^{\circ} \mathrm{C}\right)$ & $-20 \sim 55$ & $-20 \sim 50$ & $-20 \sim 60$ \\
\hline Advantages & $\begin{array}{l}\text { 1. Simple process } \\
\text { 2. High volumetric capacity }\end{array}$ & $\begin{array}{c}\text { 1. Cheap } \\
\text { 2. Simple process }\end{array}$ & $\begin{array}{l}\text { 1. Cheap } \\
\text { 2. Eco-friendly } \\
\text { 3. Safe }\end{array}$ \\
\hline Disadvantages & $\begin{array}{l}\text { 1. Expensive } \\
\text { 2. Toxic }\end{array}$ & $\begin{array}{c}\text { 1. Capacity fades } \\
\text { at elevated } \\
\text { temperature }\end{array}$ & $\begin{array}{l}\text { 1. Low conductivity } \\
\text { 2. Complex process } \\
\text { 3. Low volumetric } \\
\text { Capacity }\end{array}$ \\
\hline Applied Areas & Portable Devices & Electric Vehicles & Electric Vehicles \\
\hline
\end{tabular}

\section{ANODES}

The materials for the ideal anode of rechargeable lithium batteries should have following properties: First, the anode materials may have the ability to reversibly intercalate/deintercalate $\mathrm{Li}$ ion, at a large capacity and low potential. Similar to cathode materials, the anode materials should suffer minimal structural and redox potential change during the $\mathrm{Li}$ ion intercalation/deintercalation. These two requirements are important for good cycle performance and a smooth charge/discharge curve. Second, the anode materials should have high electronic conductivity, high $\mathrm{Li}$ ion diffusion rate and conductivity. Lastly, the anode materials should form a good solid-electrolyte interface with electrolytes at the first circle, and remain chemically stable with the electrolyte in the subsequent cycles.

Carbon-based materials are generally used in commercial $\mathrm{Li}$ ion batteries as the anode. However, based on the limitation of the theoretical gravimetric capacities of these materials (372 $\mathrm{Ah} \mathrm{Kg}^{-1}, \mathrm{LiC}_{6}$ ), many efforts have been carried out to develop higher capacity anode materials, such as Li-based materials, Tin-based materials, Transition-metal oxides and silicon. The advantages and disadvantages of different types of anode materials are discussed below.

\subsection{Li-Based Materials}

Lithium is a most electropositive $(-3.04 \mathrm{~V}$ versus standard hydrogen electrode) as well as the lightest metal in the elemental table [3]. As an anode material, it has a theoretical capacity of $3860 \mathrm{Ah} \mathrm{Kg}^{-1}$. However, lithium can react with organic electrolytes, resulting in an insulating layer or gas evolution, thus increasing the internal pressure in the cell. Meanwhile, lithium dendrites form on the lithium electrode surface during charge/discharge, bringing in two serious results: a gradual fading of capacity due to the fracture of dendrites, and internal short circuiting of cells due to the penetration of dendrites through the separator. Ionic conductors, lithium phosphorus oxynitride, lithium nitride, lithium superionic conductors (LISICON) and different electrolytes have been used to restrain the formation of lithium dendrites [52-60].

In order to improve the safety of lithium batteries, $\mathrm{Li}_{3}$ ${ }_{\mathrm{x}} \mathrm{Co}_{\mathrm{x}} \mathrm{N}(\mathrm{x}=0.1 \sim 0.6)$ was used as a new material to substitute the existing lithium anode. Despite the large and reversible capacity (760 $\mathrm{Ah} \mathrm{Kg}^{-1}$ or $1500 \mathrm{Ah} \mathrm{L}^{-1}$ ), moisture sensitivity can restrict the practical use of this material [61].

\subsection{Carbon-Based Materials}

In commercial $\mathrm{Li}$ ion batteries, soft carbon (such as nature graphite) and hard carbon (such as pyrolytic carbon from polymer) are widely used as the anode, because of theirs low and smooth charge/discharge potential, and good cycle performance. It has some shortcomings, however, such as low capacity (372 $\mathrm{Ah} \mathrm{Kg}^{-1}$ or $830 \mathrm{Ah} \mathrm{L}^{-1}$ ), bad performance under high charge/discharge rates (lithium can deposit on the surface of graphite), and cointercalation of organic solvent into graphite $[62,63]$. Many current research efforts are focused on searching for new materials to substitute graphite anodes.

Graphene is a two-dimensional aromatic monolayer of carbon atoms. It has been proposed that $\mathrm{Li}$ ion could be adsorbed on both sides of graphene sheets, which leads to two layers of lithium for each graphene sheet, with a theoretical capacity of $744 \mathrm{Ah} \mathrm{Kg}^{-1}$ through the formation of $\mathrm{Li}_{2} \mathrm{C}_{6}[64,65]$. It was reported that the electrochemical performances were supposed to be greatly enhanced if combined with $\mathrm{Fe}_{3} \mathrm{O}_{4}$ nanoparticles and graphene [66]. The $\mathrm{Fe}_{3} \mathrm{O}_{4}$ nanoparticles were dispersed on graphene sheets via microwave irradiation synthesis. As anode materials for $\mathrm{Li}$ ion batteries, they showed high reversible capacities, as well as significantly enhanced cycling performances (about 650 $\mathrm{Ah} \mathrm{Kg}^{-1}$ after 50 cycles) and high rate capabilities (350 Ah $\mathrm{Kg}^{-1}$ at $5 \mathrm{C}$ ), which might be attributed to graphene sheets not only acted as electron conductors, but also buffers which accommodated the strains of $\mathrm{Li}$ ion insertion/extraction and relieved the strain associated with the volume variations during cycles. 


\subsection{Tin-Based Materials}

Lithium will form alloys with some metals under certain conditions, in which $\mathrm{Li}$ ion can reversibly intercalate/deintercalate. Metals and alloys have been investigated for anode application since 1970, and have a much larger capacity than that of graphite. A commercial battery based on a low-melting alloy (an alloy of $\mathrm{Bi}, \mathrm{Pb}, \mathrm{Sn}$ and Cd) for anodes was introduced in the 1980s [67, 68].

$\mathrm{Li}_{22} \mathrm{Sn}_{5}$ has a high theoretical capacity of $990 \mathrm{Ah} \mathrm{Kg}^{-1}$ or $7200 \mathrm{Ah} \mathrm{L}^{-1}$. However, the volume and composition of this kind of alloy change during the electrochemical reaction, leading to fragmentation of the alloy $[69,70]$.

Intermetallic compounds $\mathrm{MM}^{\prime}$ ( $\mathrm{M}$ is an "active" element, can form an alloy with lithium, and $\mathrm{M}^{\prime}$ is an "inactive" element, cannot form an alloy with lithium) have been used as anode materials, and the cycling performance of these compounds can be improved significantly if the active alloy element is finely dispersed completely in an inactive matrix [71]. Therefore, it is believed that the inactive species provides structural stability and combats the expansion of the alloy composite. The reversible reactivity of intermetallic compound $\mathrm{SnFe}$ with $\mathrm{Li}$ ion has been explored for an anode material [72-74]. The benefit arises from the alloy formation between $\mathrm{Li}$ ion and $\mathrm{Sn}$ atoms at the grain boundaries of $\mathrm{SnFe}_{3}$ particles [75]. However, the cycling performance was improved at the expense of the capacity. Another approach to improve the cycling performance was that $\mathrm{Li}$ ion could be intercalated into the intermetallic compound $\mathrm{Cu}_{6} \mathrm{Sn}_{5}$ to yield the product $\mathrm{Li}_{13} \mathrm{Cu}_{6} \mathrm{Sn}_{5}$ with the volumetric capacity of 2964 $\mathrm{Ah} \mathrm{L}{ }^{-1}$. In addition, Li ion does not alloy or react with the "inactive" component (i.e., $\mathrm{Cu}$ ), which further increases the stability of the anode. Note that $\mathrm{Cu}_{6} \mathrm{Sn}_{5}$ has relatively small irreversible capacities compared to tin oxides [76].

Tin-based amorphous oxides, $\mathrm{SnM}_{\mathrm{x}} \mathrm{O}_{\mathrm{y}}(\mathrm{M}$ is $\mathrm{B}, \mathrm{P}$ or Al, $\mathrm{x} \geq 1$ ), have a high volumetric specific capacity of more than $2200 \mathrm{Ah} \mathrm{L}^{-1}$. In these compounds, Sn forms the electrochemically active center for $\mathrm{Li}$ ion intercalation, and the other metal group provides an electrochemical inactive network of -(M-O)- bonding, to confer high reversibility in $\mathrm{Li}$ ion storage and release [77, 78]. This type of the material has not been commercialized because of poor long-term cyclability and the fact that a large amount of the capacity is irreversibly lost during the first cycle (because many Li ions have reacted to form $\mathrm{Li}_{2} \mathrm{O}$ and solid-electrolyte interface film).

Tin-transition metal-carbon (Sn-TM-C) alloys have been used to replace graphite as the anode for Li ion batteries [79]. The Sony Corporation launched in 2005 a Li ion battery that uses a "tin-based amorphous anode" comprising tin, cobalt and carbon as the anode [80]. The Sn-Co-C system has been proposed to be the best choice among Sn-TM-C (TM= transition metal) for anodes in $\mathrm{Li}$ ion batteries since a nanostructure consisting of amorphous CoSn grains in a carbon matrix is formed during sputtering or during mechanical milling [81-83]. It was reported that $\mathrm{Sn}_{30} \mathrm{Co}_{30} \mathrm{C}_{40}$ had good capacity retention for at least 100 cycles at around $425 \mathrm{Ah} \mathrm{Kg}^{-1}$, and $\mathrm{Sn}_{30} \mathrm{Co}_{15} \mathrm{TM}_{15} \mathrm{C}_{40}$ also showed good capacity retention for at least 100 cycles ranging from 270

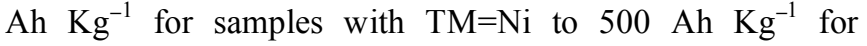
samples with $\mathrm{TM}=\mathrm{Ti}$, which might be attributed to the desired nanostructured-type XRD pattern [84].

\subsection{Transition-Metal Oxides}

Transition-metal oxides (MO) were proposed as anode materials for their large capacity at low potentials $[85,86]$. The reaction mechanism between $\mathrm{MO}(\mathrm{M}$ is $\mathrm{Co}, \mathrm{Ni}, \mathrm{Cu}$ or $\mathrm{Fe}$ ) and $\mathrm{Li}$ ion differs from the classical $\mathrm{Li}$ ion intercalation/deintercalation or Li-alloying processes [87]. It involves the composition and decomposition of $\mathrm{Li}_{2} \mathrm{O}$, accompanied with the reduction and oxidation of the transition metal, respectively. The capacities of these transition-metals are all greater than $700 \mathrm{Ah} \mathrm{Kg}^{-1}$, with high capacity retention and high recharging rate. These systems hold much promise for future development.

Among MO materials, the capacities of Ti-based oxides are less than half that of graphite $\left(175 \mathrm{Ah} \mathrm{Kg}^{-1}\right.$ for $\mathrm{Li}_{4} \mathrm{Ti}_{5} \mathrm{O}_{12}$ ). However, these materials have many advantages, such as outstanding stability, rapid charge rate, and wide operating temperature (range from $-50{ }^{\circ} \mathrm{C}$ to $75{ }^{\circ} \mathrm{C}$ ). The combination of these advantages results in ultra long durability (around 20 years) and cycle life (9000 cycles). In addition, these batteries do not explode or result in thermal runaway under harsh conditions $[88,89]$.

\subsection{Silicon}

Among all the compounds proposed to replace the graphite anode, silicon is very promising because it has a theoretical specific capacity of $4200 \mathrm{Ah} \mathrm{Kg}^{-1}$ (for $\mathrm{Li}_{22} \mathrm{Si}_{5}$ ) $[90,91]$. Moreover, silicon is the second most abundant element on earth and already has a mature industrial infrastructure in existence. It is an attractive material when considering commercial applications. But the biggest holdback preventing the commercial application of silicon is the large inherent change in specific volume (up to about $410 \%$ ) during the intercalation/deintercalation of $\mathrm{Li}$ ion. This causes crumbling, and a loss of electrical contact between the active material and the current collector [69, 92-95]. Recently, Si nanowires were developed as the anode material to accommodate the large volume change and to avoid capacity loss during cycling [96-102]. In addition, nanowires form direct chemical bonds with the current collector for good adhesion and electron transport, which makes the binding polymer and conducting graphite unnecessary. The observed specific capacity was about $2800 \mathrm{Ah} \mathrm{Kg}^{-1}$ [84]. Yushin et al. conducted a large-scale hierarchical bottom-up assembly route for the formation of $\mathrm{Si}$ on the nanoscalecontaining rigid and robust spheres with irregular channels for rapid access of Li ions into the particle bulk. Reversible capacities of the C-Si nanocomposite reached up to 1,950 Ah $\mathrm{Kg}^{-1}$, which is over five times higher than that of the theoretical capacity of graphite $[103,104]$.

The capacity of different anode materials is shown in Fig. (3). Despite many candidates for anode materials, graphite is the only widely used commercial anode material. Other anode materials, such as $\mathrm{Li}_{4} \mathrm{Ti}_{5} \mathrm{O}_{12}$ and $\mathrm{Li}_{22} \mathrm{Sn}_{5}$, are currently on a small scale application. Looking into the future, the trend of anode materials may shift to high capacity lithium or silicon materials. 


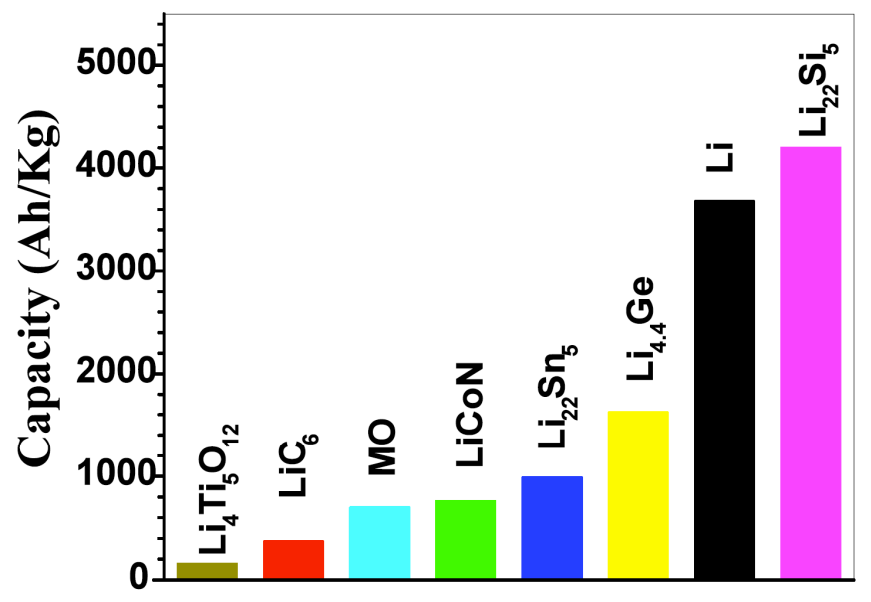

Fig. (3). The capacity of different anode materials.

\section{ELECTROLYTES}

Electrolyte is one of the key components of a battery, which is commonly referred to as a solution comprising solvents and salts (such as $\mathrm{LiPF}_{6}$, which is well known for its rapid dissolution in carbonate solvents, lower cost and good conductivity $[105,106])$. The choice of electrolytes is very crucial, and depends on the choice of the anode and the cathode. For instance, graphite anodes operate in a highly reducing voltage range $(<1.2 \mathrm{~V} v s$ lithium), at which point most electrolytes are thermodynamically reduced. To ensure reversible behavior, the deposition of an efficient passivating layer at the graphite surface is necessary during the first cycle. The electrolyte was probably oxidized when the lithium oxide cathode materials were charged up to more than $4 \mathrm{~V}$ vs lithium [7, 107]. Electrolyte oxidation leads to irreversible loss of capacity, because of the generation of new chemical species, which deposit on the electrode surface as an insulating layer or evolve as a gas, thus increasing the internal pressure in the cell. Electrolyte oxidation is believed to be the main failure mechanism for rocking-chair technology [108]. Thus, minimizing electrolyte oxidation is a major requirement in enhancing the cycle life and improving the performance of lithium batteries at elevated temperatures. Fortunately, the electrolyte oxidation reaction is limited. Most of the electrolytes can be used beyond the voltage range of their thermodynamic stability [108].

\subsection{Traditional Organic Liquids}

There are numerous liquid compounds available to be selected as electrolytes. Viscosity, dielectric constants and ionic conductivity of an organic liquid should be considered first to determine a suitable electrolyte. Most liquid electrolytes are composed of ethylene carbonate (EC) and dimethyl carbonate (DMC). EC is present in almost all commercial compositions, because of its low cost, good electrochemical stability, and high dielectric constant which permits better ionic dissociation of the salt and improves the ionic conductivity. Furthermore, it can provide a protective layer on the surface of graphite that prevents further reaction [109]. However, a pure EC-based electrolyte was not used because of its high freezing point $\left(35-38{ }^{\circ} \mathrm{C}\right)$, which is not compatible with practical application. DMC, commonly known as a thinning solvent, is used with EC to reduce the viscosity. Note that a pure DMC-based electrolyte is not compatible with graphite anodes, since no passivation layer can build up during cycling [108]. In general, the traditional liquid electrolytes have several disadvantages, such as flammability and a narrow range of operating temperatures [110]. These problems could be solved by novel electrolytes such as ionic liquids, organic solid electrolytes or inorganic solid electrolytes.

\subsection{Ionic Liquids}

Ionic liquids as electrolytes for lithium batteries have been studied in recent years [111-113]. The ionic liquids are nonflammable as they contain no volatile compound. In addition, they show a broad electrochemical stability window (generally $>4 \mathrm{~V}$ ). Early attempts to cycle $\mathrm{Li}$ ion batteries using electrolytes on the basis of ionic liquids failed because of electrolyte reduction occurring at the low potential [114]. One type of good ionic liquid utilized as an electrolyte is an aluminum chloride $\left(\mathrm{AlCl}_{3}\right)$ based solution. However, $\mathrm{AlCl}_{3}$ is toxic and difficult to process [115-117]. $\mathrm{N}$-methyl-N-propylpiperidinium-bis

(trifluoromethylsulfonyl) imide [111] and nhexyltrimethylammonium-bis (trifluoromethylsulfonyl) imide [118] $\left(\mathrm{AlCl}_{3}\right.$-free ionic liquids) were successfully developed and have been used as electrolytes. Highly reversible and stable cycling have also been obtained using 1-ethyl-3-methylimidazolium-bis (trifluoromethylsulfonyl) imide as the electrolyte [119]. A solvent-free, ternary polymer electrolytes based on a novel poly (diallyldimethylammonium) bis (trifluoromethanesulfonyl) imide polymeric ionic liquid (PIL) as polymer host and incorporating PYR14TFSI ionic liquid and LiTFSI salt are reported (Ternary polymer electrolytes containing pyrrolidinium-based polymeric ionic liquids for lithium batteries) [120]. The PIL-based polymer electrolytes exhibited room temperature ionic conductivity above $10^{-4} \mathrm{~S}$ $\mathrm{cm}^{-1}$, and the Li/PIL-LiTFSI-PYR14TFSI $/ \mathrm{LiFePO}_{4}$ solidstate batteries are capable to deliver above $140 \mathrm{Ah} \mathrm{Kg}^{-1}$ at 40 ${ }^{\circ} \mathrm{C}$. Over all, still only a few ionic liquid electrolytes have been found suitable for lithium batteries because of their high viscosity issues [121].

\subsection{Organic Solid Electrolytes}

Many efforts have been dedicated to develop all-solidstate $\mathrm{Li}$ ion batteries [2]. Organic polymers (rubbery electrolytes) are the promising candidates. Polymer electrolytes are commonly composed of a lithium salt (LiX) and a high-molecular-weight polymer such as polyethylene oxide (PEO). However, PEO crystallization below $60{ }^{\circ} \mathrm{C}$ is a challenge for electrolyte application at lower temperature. As a result, PEO-LiX electrolytes work only at temperatures above $60{ }^{\circ} \mathrm{C}$. The most common approach for lowering the operational temperature is adding liquid plasticizers (such as propylene carbonate or polyethylene glycol ethers) or gels (contain 60-95\% liquid) [122]. But this method promotes the deterioration of the electrolyte's mechanical properties and increases its reactivity towards the lithium anode. A series of "polymer-in-salt" materials were developed as electrolytes, in which lithium salts were mixed with small quantities of the polymers, e.g., polypropylene oxide and polyethylene oxide. The glass transition temperature of these materials is low enough to remain rubbery at room temperature with good Li ion conductivity and high electrochemical stability 
[123]. When using $\mathrm{TiO}_{2}$ or $\mathrm{Al}_{2} \mathrm{O}_{3}$ nanoparticles as solid plasticizers in PEO, a solid-state polymer electrolyte has been developed [124]. The conductivity of these electrolytes increased and the crystallization was well prevented. Li ion doped plastic crystalline matrixes are stable over a potential of $5 \mathrm{~V}$ and very attractive for battery applications in combination of possible structural variations of plastic crystal matrixes and conductivities [125]. Huang et al. have prepared a novel solid-state composite polymer electrolyte based on poly (ethylene oxide) (PEO) by using $\mathrm{LiClO}_{4}$ as doping salts and inorganic-organic hybrid poly (cyclotriphosphazene-co-4, 40-sulfonyldiphenol) (PZS) microspheres as fillers [126]. Compared with traditional ceramic fillers such as $\mathrm{SiO}_{2}$, PZSMS in PEO-based polymer electrolytes leads to higher enhancement in ionic conductivity.

\subsection{Inorganic Solid Electrolytes}

Other promising candidates for solid electrolytes are inorganic materials (brittle superionic glass electrolytes). For inorganic solid electrolytes, lithium superionic conductors (LISICON) are very importance with respect to achieving an all solid-state lithium battery. This technology may solve the safety problems of the rechargeable $\mathrm{Li}$ ion batteries using nonaqueous liquid electrolytes. In $1978, \mathrm{Li}_{14} \mathrm{Zn}\left(\mathrm{GeO}_{4}\right)_{4}$, a type of LISICON was found [127], which attracted attention for its potential application as a solid electrolyte [128].

A new solid system based on lithium germanium sulfide and lithium silicon sulfide was found [129, 130], named "thio-LISICON". This is the first example of crystalline ionic conductor with a high ionic conductivity and high decomposition potential at room temperature. Sulfide-based electrolytes generally have a higher Li ion conductivity, by several orders of magnitude, compared with oxide-based electrolytes. For example, the Li ion conductivity of thioLISICON is around $10^{-3} \mathrm{~S} \mathrm{~cm}^{-1}$ for $\mathrm{Li}_{3.25} \mathrm{Ge}_{0.25} \mathrm{P}_{0.75} \mathrm{~S}_{4}$, four orders of magnitude higher than $\mathrm{Li}_{14} \mathrm{Zn}\left(\mathrm{GeO}_{4}\right)_{4}$, a typical oxide LISICON.

The thio-LISICON has high electrochemical stability, which is important for all solid-state lithium batteries. Many studies focused on the binary $\mathrm{Li}_{2} \mathrm{~S}-\mathrm{P}_{2} \mathrm{~S}_{5}$ system [131]. $70 \mathrm{Li}_{2} \mathrm{~S}-30 \mathrm{P}_{2} \mathrm{~S}_{5}(\mathrm{~mol} \%)$ glass was prepared by a quenching melt techniques [132]. The obtained glass-ceramic showed high $\mathrm{Li}$ ion conductivity of $2.1 \times 10^{-3} \mathrm{~S} \mathrm{~cm}^{-1}$ at room temperature. Glass-ceramic $\mathrm{Li}_{2} \mathrm{~S}_{-} \mathrm{P}_{2} \mathrm{~S}_{5}$ electrolytes were prepared by a single step ball milling process at $55^{\circ} \mathrm{C}$ [133]. The produced crystalline glass-ceramic materials exhibit high $\mathrm{Li}$ ion conductivity over $10^{-3} \mathrm{~S} / \mathrm{cm}$ at room temperature with a wide electrochemical stability window of $5 \mathrm{~V}$.

Ideally, liquid electrolytes will be replaced by solid state electrolytes that can perform similarly without excessive safety issues [134]. The current barriers with solid state electrolytes include inferior charge/discharge rate, ionic conductivity, interfacial stability and mechanical strength $[135,136]$. Efforts have been carried out to find a solid state electrolyte that can outperform liquid electrolytes.

\section{SEPARATORS}

A separator is an important component of a battery cell, as it prevents short circuit by separating the anode from the cathode, as well as providing passages for Li ion [137]. In a
Li ion battery, the separator is required to be capable of battery shutdown at the temperature below that at which thermal runaway occurs, and the shutdown should not result in loss of mechanical integrity. Otherwise, the electrodes could come into direct contact and the resulting chemical reactions cause thermal runaway [111]. Shutdown is an important trait of a good separator for the safety of lithium batteries. The promising separators are those with high electrolyte permeability and mechanical strength, as well as good thermal, chemical, and electrochemical stability.

\subsection{Organic Separators}

In commercially available lithium batteries, microporous membranes fabricated from polyethylene (PE) and polypropylene (PP) are used as separators [138-140]. These polyolefin separators are suitable for batteries, since they can be used for hundreds of cycles without any chemical or physical degradation. The collapse of the pores occurs when the temperature approaches the melting point of the material, which forms a nonporous insulated film and results in a sharp increase in impedance. Since the impedance of a PP separator increases less than that of a PE separator, the impedance of the PP separator may not be large enough for complete shutdown, and thermal runaway could still happen. Therefore, $\mathrm{PE}$ is the preferred separator material for most $\mathrm{Li}$ ion batteries [141, 142]. Robust mechanical properties of the separator are expected even above the shutdown temperature because the battery temperature may increase continuously after shutdown. When the separator undergoes a meltdown, the mechanical properties of the separator could deteriorate greatly and the cell may experience an internal short circuit, resulting in a hazard. The shutdown temperature of a separator should be lower than its meltdown temperature. A sandwiched separator containing one porous PE layer between two porous PP layers (PP-PE-PP trilayer) has been made to maintain the robust mechanical properties. The PE layer offers a lower shutdown temperature; whereas the PP provides mechanical stability above the shutdown temperature (such as Celgard $\AA$ [143]). The shutdown temperature and meltdown temperature were increased to $142{ }^{\circ} \mathrm{C}$ and $155{ }^{\circ} \mathrm{C}$ respectively, when the separator was coated with diethylene glycol dimethacrylate [144]. When silica nanoparticles were added to the separator, the meltdown temperature increased to $170{ }^{\circ} \mathrm{C}$ [145]. Polyolefin membrane separators, however, have several drawbacks, such as large thermal shrinkage near its melting/softening temperature, low porosity and low wettability in electrolyte solutions. Silica-composite nonwovens using polyolefin fiber and nanosize silica powder showed not only better wettability than the polyolefin-based membrane and nonwoven, but also thermal shrinkage of $\sim 3 \%$ at $160{ }^{\circ} \mathrm{C}$ under air atmosphere and thermally stable at $150{ }^{\circ} \mathrm{C}$ in the liquid electrolyte [146].

\subsection{Inorganic Separators}

Separators can also be made of inorganic sub-micron sized particles and a small amount of polymer binder, which have dimensional stability at a high temperature as well as wettability [147]. This type of separator is highly desirable for the development of large-size lithium batteries, especially those installed in electric vehicles and power tools. Nonwoven support materials can improve the mechanical 
strength of inorganic separators [146]. Recently, nonwoven supported inorganic separators prepared via a sol-gel coating method were commercialized for $\mathrm{Li}$ ion batteries [148, 149]. Kim et al. prepared an inorganic separator by coating inorganic submicrometer sized $\mathrm{Al}_{2} \mathrm{O}_{3}$ particles on a nonwoven matrix Aramid fiber followed by an E-beam irradiation treatment [150]. The mechanical and thermal properties of the separator were greatly enhanced by the simple curing under E-beam irradiation. Remarkable improvements of the separators with respect to the battery safety have been demonstrated by a series of abuse tests. However, the practical application of the inorganic particle coated nonwoven separators using polymeric binders has not been realized, because of insufficient mechanical strength to withstand the roll-to-roll manufacturing process [150].

\section{CONCLUSIONS}

The performance of rechargeable lithium batteries depends on the properties of cathodes, anodes, electrolytes and separators. The discovery of intercalation materials has played a significant role in increased performance. The intercalation materials, such as the graphite anode and the $\mathrm{LiCoO}_{2}$ cathode, impact the large scale commercialization of rechargeable lithium batteries. Besides intercalation materials, the application of nanostructured materials results in substantial improvements of rechargeable lithium batteries. Currently, lithium cobalt oxide, lithium manganese oxide and lithium iron phosphate are the most used cathode materials. Other promising cathode materials, such as sulfur and lithium sulfide, are under development. In the area of anode materials, graphite is the most widely used. However, the tin-based anode material technology is maturing, and the lithium or silicon-based materials are also becoming next generation anode materials. In the past, lithium was chosen as the anode material of lithium batteries due to its largest theoretical energy density. However, the market for lithium anodes has dropped due to safety concerns and battery stability. As shown in Fig. (1), the highest energy density of existing $\mathrm{Li}$ ion batteries is only about $150 \mathrm{Wh} \mathrm{Kg}^{-1}$ or 300 $\mathrm{Wh} \mathrm{L}^{-1}$, and the maximum energy density of the ideal $\mathrm{Li}$ ion batteries is about $580 \mathrm{Wh} \mathrm{kg}^{-1}$ or $1810 \mathrm{Wh} \mathrm{L}^{-1}$. The ideal lithium-sulfur (Li-S) battery has a much higher energy density of $2500 \mathrm{Wh} \mathrm{kg}^{-1}$ or $2800 \mathrm{Wh} \mathrm{L}^{-1}$. In this regard, the Li-S battery may be the rechargeable lithium battery of the future.

From potable electronics to electric vehicles or hybrid electric vehicles, power sources that have a high charge/discharge rate, high power density, long cycle life, and safe operation are in constant demand. The successful design of new assembly technology, discovery of new materials, and development of new theories will promote the development of next generation rechargeable lithium batteries.

\section{REFERENCES}

[1] Howell D. Progress Report for Energy Storage Research and Development. U. S. Department of Energy 2009.

[2] Tarascon J-M, Armand M. Issues and challenges facing rechargeable lithium batteries. Nature 2001; 414: 359-67.

[3] Arico AS, Bruce P, Scrosati B, Tarascon JM, Van Schalkwijk W. Nanostructured materials for advanced energy conversion and storage devices. Nat Mater 2005; 4 (5): 366-77.

[4] Tollefson J. Charging up the future. Nature 2008; 456: 436-40.
[5] Thomas M, David WIF, Goodenough JB, Groves P. Synthesis and structural characterization of the normal spinel $\mathrm{LiNi}_{2} \mathrm{O}_{4}$. Mater Res Bull 1985; 20 (10): 1137-46.

[6] Dahn JR, Vonsacken U, Michal CA. Structure and electrochemistry of $\mathrm{Li}_{1 \pm y} \mathrm{NiO}_{2}$ and a new $\mathrm{Li}_{2} \mathrm{NiO}_{2}$ phase with the $\mathrm{Ni}(\mathrm{OH})_{2}$ structure. Solid State Ionics 1990; 44 (1-2), 87-9.

[7] Dahn JR, Vonsacken U, Juzkow MW, Aljanaby H. Rechargeable $\mathrm{LiNiO}_{2}$ carbon cells. J Electrochem Soc 1991; 138 (8): 2207-11.

[8] Plichta E, Salomon M, Slane S, et al. A rechargeable $\mathrm{Li} / \mathrm{Li}_{\mathrm{x}} \mathrm{CoO}_{2}$ cell. J Power Sources 1987; 21: 25-31.

[9] Wang F, Yang J, NuLi YN, Wang JL. Highly promoted electrochemical performance of $5 \mathrm{~V} \mathrm{LiCoPO}_{4}$ cathode material by addition of vanadium. J Power Sources 2010; 195 (19): 6884-7.

[10] Ohzuku $\mathrm{T}$, Yanagawa $\mathrm{T}$, Kouguchi $\mathrm{M}$, Ueda A. Innovative insertion material of $\mathrm{LiAl}_{1 / 4} \mathrm{Ni}_{3 / 4} \mathrm{O}_{2}$ (R $\overline{3} \mathrm{~m}$ ) for lithium-ion (shuttlecock) batteries. J Power Sources 1997; 68 (1): 131-4.

[11] Gao Y, Yakovleva MV, Ebner WB. Novel $\mathrm{LiNi}_{1-\mathrm{x}} \mathrm{Ti}_{\mathrm{x} / 2} \mathrm{Mg}_{\mathrm{x} / 2} \mathrm{O}_{2}$ compounds as cathode materials for safer lithium-ion batteries. Electrochem Solid State Lett 1998; 1: 117-9.

[12] Sun YK, Myung ST, Kim MH, Prakash J. Amine K, Synthesis and characterization of $\mathrm{Li}\left[\left(\mathrm{Ni}_{0.8} \mathrm{Co}_{0.1} \mathrm{Mn}_{0.1}\right)_{0.8}\left(\mathrm{Ni}_{0.5} \mathrm{Mn}_{0.5}\right)_{0.2}\right] \quad \mathrm{O}_{2}$ with the microscale core-shell structure as the positive electrode material for lithium batteries. J Am Chem Soc 2005; 127 (38): 13411-8.

[13] Sun YK, Myung ST, Park BC, Prakash J, Belharouak I, Amine K. High-energy cathode material for long-life and safe lithium batteries. Nat Mater 2009; 8: 320-4.

[14] Guyomard D, Tarascon JM. Rechargeable $\mathrm{Li}_{1+\mathrm{x}} \mathrm{Mn}_{2} \mathrm{O}_{4} /$ carbon cells with a new electrolyte- composition-potentiostatic studies and application to practical cells. J Electrochem Soc 1993; 140 (11): 3071-81.

[15] Tarascon JM, Wang E, Shokoohi FK, McKinnon WR, Colson S. The spinel phase of $\mathrm{LiMn}_{2} \mathrm{O}_{4}$ as a cathode in secondary lithium cells. J Electrochem Soc 1991; 138 (10): 2859-64.

[16] Tarascon JM, Guyomard D. Li metal-free rechargeable batteries based on $\mathrm{Li}_{1+\mathrm{X}} \mathrm{Mn}_{2} \mathrm{O}_{4}$ cathodes $(0 \leq \mathrm{x} \leq 1)$ and carbon anodes. $\mathrm{J}$ Electrochem Soc 1991; 138 (10): 2864-8.

[17] Gummow RJ, Liles DC, Thackeray MM. Lithium extraction from orthorhombic lithium manganese oxide and the phase transformation to spinel. Mat Res Bull 1993; 28: 1249-56.

[18] Armstrong AR, Bruce PG. Synthesis of layered $\mathrm{LiMnO}_{2}$ as an electrode for rechargeable lithium batteries. Nature 1996; 381 (6582): 499-500.

[19] Cho J, Park B. $\mathrm{Li}_{2+\mathrm{x}} \mathrm{Mn}_{0.91} \mathrm{Cr}_{1.09} \mathrm{O}_{4}$ cathode materials for $\mathrm{Li}$-ion cells. Electrochem Solid State Lett 2000; 3 (8): 355-8.

[20] Davidson IJ, McMillan RS, Slegr H, et al. Electrochemistry and structure of $\mathrm{Li}_{2-\mathrm{x}} \mathrm{Cr}_{\mathrm{y}} \mathrm{Mn}_{2-\mathrm{y}} \mathrm{O}_{4}$ phases. J Power Sources 1999; 81: 406-11.

[21] Dahn JR, Zheng T, Thomas CL. Structure and electrochemistry of $\mathrm{Li}_{2} \mathrm{Cr}_{\mathrm{x}} \mathrm{Mn}_{2-\mathrm{x}} \mathrm{O}_{4}$ for $1.0 \leq \mathrm{x} \leq 1.5$. J Electrochem Soc 1998; 145 (3): $851-9$.

[22] Jang YI, Huang BY, Chiang YM, Sadowa DR. Stabilization of $\mathrm{LiMnO}_{2}$ in the $\alpha-\mathrm{NaFeO}_{2}$ structure type by $\mathrm{LiAlO}_{2}$ addition. Electrochem Solid State Lett 1998; 1:13-6.

[23] Thackeray MM. Manganese oxides for lithium batteries. Prog Solid State Chem 1997; 25 (1-2): 1-71.

[24] Yuan AB, Tian L, Xu WM, Wang YQ. Al-doped spinel $\mathrm{LiAl}_{0.1} \mathrm{Mn}_{1.9} \mathrm{O}_{4}$ with improved high-rate cyclability in aqueous electrolyte. J Power Sources 2010; 195 (15): 5032-8.

[25] Amatucci G, Du Pasquier A, Blyr A, Zheng T, Tarascon JM. The elevated temperature performance of the $\mathrm{LiMn}_{2} \mathrm{O}_{4} / \mathrm{C}$ system: Failure and solutions. Electrochim Acta 1999; 45 (1-2): 255-71.

[26] Amatucci GG, Pereira N, Zheng T, Tarascon JM. Failure mechanism and improvement of the elevated temperature cycling of $\mathrm{LiMn}_{2} \mathrm{O}_{4}$ compounds through the use of the $\mathrm{LiAl}_{x} \mathrm{Mn}_{2-\mathrm{x}} \mathrm{O}_{4-\mathrm{z}} \mathrm{F}_{\mathrm{z}}$ solid solution. J Electrochem Soc 2001; 148 (2): A171-82.

[27] Amatucci GG, Blyr A, Sigala C, Alfonse P, Tarascon JM. Surface treatments of $\mathrm{Li}_{1+\mathrm{x}} \mathrm{Mn}_{2-\mathrm{x}} \mathrm{O}_{4}$ spinels for improved elevated temperature performance. Solid State Ionics 1997; 104 (1-2): 1325.

[28] Wang EI, Mass M. Methode of Treating Lithium Manganese Oxide Spinel. US5783328, July 21, 1998.

[29] Padhi AK, Nanjundaswamy KS, Goodenough JB. Phospho-olivines as positive-electrode materials for rechargeable lithium batteries. J Electrochem Soc 1997; 144 (4): 1188-94. 
[30] Goodenough JB, Padhi AK, Nanjundaswamy KS, Masquelier C. Cathode materials for secondary (rechargeable) lithium batteries. US5910382, June 8, 1999.

[31] Herle PS, Ellis B, Coombs N, Nazar LF. Nano-network electronic conduction in iron and nickel olivine phosphates. Nat Mater 2004; 3 (3): $147-52$

[32] Wang YG, Wang YR, Hosono E, Wang KX, Zhou HS. The design of a LiFePO4/Carbon nanocomposite with a core-shell structure and its synthesis by an in situ polymerization restriction method. Angew Chem Int Ed 2008; 47: 7461-5.

[33] Ravet N, Abouimrane A, Armand M. From our readers. Nat Mater 2003; 2: 702 .

[34] Sun YK, Oh SM, Myung ST, Amine K, Scrosati B. 15th International Meeting on Lithium Batteries; July 2010; Montréal, Québec, Canada; 1010.

[35] Chung SY, Bloking JT, Chiang YM. Electronically conductive phospho-olivines as lithium storage electrodes. Nat Mater 2002; 1 (2): 123-8.

[36] Guo YG, Hu JS, Wan LJ. Nanostructured materials for electrochemical energy conversion and storage devices. Adv Mater 2008; 20 (15): 2878-87.

[37] Wu SH, Chen MS. 15th International Meeting on Lithium Batteries; July 2010; Montréal, Québec, Canada; 1010.

[38] Chang ZR, Lv HJ, Tang H, Yuan XZ, Wang HJ. Synthesis and performance of high tap density $\mathrm{LiFePO}_{4} / \mathrm{C}$ cathode materials doped with copper ions. J Alloys Compd 2010; 501 (1): 14-7.

[39] Nishimura S, Kobayashi G, Ohoyama K, Kanno R, Yashima M, Yamada A. Experimental visualization of lithium diffusion in LixFePO4. Nat Mater 2008; 7 (9): 707-11.

[40] Ravet N, Chouinard Y, Magnan JF, Besner S, Gauthier M, Armand M. Electroactivity of natural and synthetic triphylite. J Power Sources 2001; 97-8: 503-7.

[41] Delacourt C, Poizot P, Levasseur S, Masquelier C. Size effects on carbon-free $\mathrm{LiFePO}_{4}$ powders. Electrochem Solid State Lett 2006; 9 (7): A352-5.

[42] Kim DH, Kim J. Synthesis of $\mathrm{LiFePO}_{4}$ nanoparticles in polyol medium and their electrochemical properties. Electrochem Solid State Lett 2006; 9 (9): A439-42.

[43] Kang B, Ceder G. Battery materials for ultrafast charging and discharging. Nature 2009; 458: 190-3

[44] Recham N, Chotard JN, Dupont L, et al. A 3.6 V lithium-based fluorosulphate insertion positive electrode for lithium-ion batteries. Nat Mater 2010; 9 (1): 68-74.

[45] Kolosnitsyn VS, Kuzmina EV, Karaseva EV. 15th International Meeting on Lithium Batteries; July 2010; Montréal, Québec, Canada; 1010

[46] Ji XL, Lee KT, Nazar LF. A highly ordered nanostructured carbonsulphur cathode for lithium- sulphur batteries. Nat Mater 2009; 8: 500-6.

[47] Liang CD, Dudney NJ, Howe JY. Hierarchically structured sulfur/Carbon nanocomposite material for high-energy lithium battery. Chem Mater 2009; 21: 4724-30.

[48] Hayashi A, Ohtsubo R, Ohtomo T, Mizuno F, Tatsumisago M. Allsolid-state rechargeable lithium batteries with $\mathrm{Li}_{2} \mathrm{~S}$ as a positive electrode material. J Power Sources 2008; 183 (1): 422-6.

[49] Zhou YN, Wu CL, Zhang H, Wu XJ, Fu ZW. Electrochemical reactivity of $\mathrm{Co}-\mathrm{Li}_{2} \mathrm{~S}$ nanocomposite for lithium-ion batteries. Electrochim Acta 2007; 52 (9): 3130-6.

[50] Obrovac MN, Dahn JR. Electrochemically active lithia/metal and lithium sulfide/metal composites. Electrochem Solid State Lett 2002; 5 (4): A70-3.

[51] Yang Y, McDowell MT, Jackson A, Cha JJ, Hong SS, Cui Y. New nanostructured $\mathrm{Li}_{2} \mathrm{~S} /$ silicon rechargeable battery with high specific energy. Nano Lett 2010;10: 1486-91.

[52] Chu MY. Rechargeable Positive Electrodes. US5686201, November 11, 1997.

[53] Visco SJ, Katz BD, Nimon YS, Jonghe LCD. Protected active metal electrode and battery cell structures with non-aqueous interplayer architecture. US2008/0038641A1, February 14, 2008.

[54] Skotheim TA, Sheehan CJ, Mikhaylik YV, Affinito J. Lithium anodes for electrochemical cells. US7247408B2, June 24, 2007.

[55] Visco SJ, Nimon YS, Katz BD. Ionically conductive composites for protection of active metal anode. US2008/0057387A1, March 6,2008 .
[56] Bates JB, Protective lithium ion conducting ceramic coating for lithium metal anodes and associate method. US5314765, May 24, 1994

[57] Visco SJ, Katz BD, Nimon YS, Jonghe LCD. Protected active metal electrode and battery cell structures with non-aqueous interplayer architecture. US2008/0038641A1, February 14, 2008.

[58] Visco SJ, Katz BD, Nimon YS, Jones PC. Protected active metal electrode and battery cell structures with non-aqueous interplayer architecture. US7282295B2, October 16, 2007.

[59] Visco SJ, Nimon YS, Li/air non-aqueous batteries. US2007/0117007A1, May 24, 2007.

[60] Yurity VM, Chariclea SK, Igor K, Cathie B. Separation of electrolytes. US2010/0129699A1, May 27, 2010.

[61] Shodai T, Okada S, Tobishima S, Yamabi I. Study of $\mathrm{Li}_{3-\mathrm{x}} \mathrm{M}_{\mathrm{x}} \mathrm{N}$ $(\mathrm{M}=\mathrm{Co}, \mathrm{Ni}$ or $\mathrm{Cu})$ system for use as anode in lithium rechargeable cells. Solid State Ionics 1996; 86-88: 785-9.

[62] Besenhard JO, Yang J, Winter M. Will advanced lithium-alloy anodes have a chance in lithium-ion batteries? J Power Sources 1997; 68 (1): 87-90.

[63] Winter M, Besenhard JO, Spahr ME, Novak P. Insertion electrode materials for rechargeable lithium batteries. Adv Mater 1998; 10 (10): 725-63

[64] Dahn JR, Zheng T, Liu YH, Xue JS. Mechanisms for lithium insertion in carbonaceous materials. Science 1995; 270 (5236): 590-3.

[65] Liu YH, Xue JS, Zheng T, Dahn JR. Mechanism of lithium insertion in hard carbons prepared by pyrolysis of epoxy resins. Carbon 1996; 34 (2): 193-200.

[66] Zhang M, Lei DN, Yin XM, et al. Magnetite/graphene composites: Microwave irradiation synthesis and enhanced cycling and rate performances for lithium ion batteries. J Mater Chem 2010; 20 (26):5538-43.

[67] Winter M, Besenhard JO. Electrochemical lithiation of tin and tinbased intermetallics and composites. Electrochem Acta 1999; 45: 31-50.

[68] Anani A, Crouch-Baker S, Huggins RA. Kinetic and thermodynamic parameters of several binary lithium alloy negative electrode materials at ambient temperature. J Electrochem Soc 1987; 134: 3098- 102 .

[69] Boukamp BA, Lesh GC, Huggins RA. All-solid lithium electrodes with mixed-conductor matrix. J Electrochem Soc 1981; 128 (4): 725-9.

[70] Wang JQ, Raistrick ID, Huggins RA. Behavior of some binary lithium alloys as negative electrodes in organic solvent-based electrolytes. J Electrochem Soc 1986; 133 (3): 457-60.

[71] Zhang SC, Fang Y, Xing YL, Jiang T, Sun MM. 15th International Meeting on Lithium Batteries; July 2010; Montréal, Québec, Canada; 1010

[72] Mao O, Dunlap RA, Dahn JR. Mechanically alloyed Sn-Fe(-C) powders as anode materials for $\mathrm{Li}$ - ion batteries-I. The $\mathrm{Sn}_{2} \mathrm{Fe}-\mathrm{C}$ system. J Electrochem Soc 1999, 146 (2), 405-13.

[73] Mao O, Dahn JR. Mechanically alloyed $\mathrm{Sn}-\mathrm{Fe}(-\mathrm{C})$ powders as anode materials for Li-ion batteries-II. The $\mathrm{SnFe}$ system. J Electrochem Soc 1999; 146 (2): 414-22.

[74] Mao O, Dahn JR. Mechanically alloyed Sn-Fe(-C) powders as anode materials for Li-ion batteries-III. $\mathrm{Sn}_{2} \mathrm{Fe}: \mathrm{SnFe}_{3} \mathrm{C}$ active/inactive composites. J Electrochem Soc 1999; 146 (2): 4237.

[75] Beaulieu LY, Larcher D, Dunlap RA, Dahn JR. Reaction of Li with grain-boundary atoms in nanostructured compounds. J Electrochem Soc 2000; 147 (9): 3206-12.

[76] Kepler KD, Vaughey JT, Thackeray MM. $\mathrm{Li}_{x} \mathrm{Cu}_{6} \mathrm{Sn}_{5}(0<\mathrm{x}<13)$ : An intermetallic insertion electrode for rechargeable lithium batteries. Electrochem Solid State Lett 1999; 2 (7): 307-9.

[77] Idota Y, Kubota T, Matsufuji A, Maekawa Y, Miyasaka T. Tinbased amorphous oxide: A high-capacity lithium-ion-storage material. Science 1997; 276 (5317): 1395-7.

[78] Courtney IA, Dahn JR. Electrochemical and in situ x-ray diffraction studies of the reaction of lithium with tin oxide composites. J Electrochem Soc 1997; 144 (6): 2045-52.

[79] Park MS, Kim JH, Kang YM. 15th International Meeting on Lithium Batteries; July 2010; Montréal, Québec, Canada; 1010

[80] http://www.sony.net/SonyInfo/News/Press/200502/05-006E/.

[81] Todd ADW, Mar RE, Dahn JR. Tin-transition metal-carbon systems for lithium-ion battery negative electrodes. J Electrochem Soc 2007; 154 (6): A597-604. 
[82] Ferguson PP, Todd ADW, Dahn JR. Comparison of mechanically alloyed and sputtered tin-cobalt- carbon as an anode material for lithium-ion batteries. Electrochem Commun 2008; 10 (1): 25-31.

[83] Ferguson PP, Dahn JR. Effect of annealing on $\mathrm{Sn}_{30} \mathrm{Co}_{30} \mathrm{C}_{40}$ prepared by mechanical attriting. Electrochem Solid State Lett 2008; 11 (11): A187-9.

[84] Ferguson PP, Martine ML, George AE, Dahn JR. Studies of tintransition metal-carbon and tin- cobalt-transition metal-carbon negative electrode materials prepared by mechanical attrition. J Power Sources 2009; 194 (2): 794-800.

[85] Lazzari M, Scrosati B. Rechargeable lithium batteries with nonmetal electrodes. US4464447, August 7, 1984.

[86] Idota Y. Nonaqueous Secondary battery. US5478671, December 26, 1995.

[87] Poizot P, Laruelle S, Grugeon S, Dupont L, Tarascon JM. Nanosized transition-metaloxides as negative-electrode materials for lithium-ion batteries. Nature 2000; 407 (6803): 496-9.

[88] Kavan L, Gratzel M. Facile synthesis of nanocrystalline $\mathrm{Li}_{4} \mathrm{Ti}_{5} \mathrm{O}_{12}$ (spinel) exhibiting fast Li insertion. Electrochem Solid State Lett 2002; 5 (2): A39-42.

[89] Ohzuku T, Ueda A, Yamamoto N. Zero-strain insertion material of $\mathrm{Li}\left[\mathrm{Li}_{1 / 3} \mathrm{Ti}_{5 / 3}\right] \mathrm{O}_{4}$ for rechargeable lithium cells. J Electrochem Soc 1995; 142 (5): 1431-5.

[90] Wen CJ, Huggins RA. Chemical diffusion in intermediate phases in the lithium-silicon system. J Solid State Chem 1981; 37 (3): 271-8.

[91] Loveridge M, Lain M, Liu FM, Coowar F, Macklin B, Green M. 15th International Meeting on Lithium Batteries; July 2010; Montréal, Québec, Canada; 1010.

[92] Green M, Fielder E, Scrosati B, Wachtler M, Moreno JS. Structured silicon anodes for lithium battery applications. Electrochem Solid State Lett 2003; 6 (5): A75-9.

[93] Li H, Huang XJ, Chen LQ, Wu ZG, Liang Y. A high capacity nano-Si composite anode material for lithium rechargeable batteries. Electrochem Solid State Lett 1999; 2 (11): 547-9.

[94] Graetz J, Ahn CC, Yazami R, Fultz B. Highly reversible lithium storage in nanostructured silicon. Electrochem Solid State Lett 2003; 6 (9): A194-7.

[95] Kasavajjula U, Wang CS, Appleby AJ. Nano- and bulk-siliconbased insertion anodes for lithium-ion secondary cells. J Power Sources 2007; 163 (2): 1003-39.

[96] Park MH, Kim MG, Joo J, et al. Silicon nanotube battery anodes. Nano Lett 2009; 9 (11): 3844-7.

[97] Cui LF, Yang Y, Hsu CM, Cui Y. Carbon-silicon core-shell nanowires as high capacity electrode for lithium ion batteries. Nano Lett 2009; 9 (9): 3370-4.

[98] Chan CK, Ruffo R, Hong SS, Huggins RA, Cui Y. Structural and electrochemical study of the reaction of lithium with silicon nanowires. J Power Sources 2009; 189 (1): 34-9.

[99] Chan CK, Ruffo R, Hong SS, Cui Y. Surface chemistry and morphology of the solid electrolyte interphase on silicon nanowire lithium-ion battery anodes. J Power Sources 2009; 189 (2): 113240.

[100] Cui LF, Ruffo R, Chan CK, Peng HL, Cui Y. Crystallineamorphous core-shell silicon nanowires for high capacity and high current battery electrodes. Nano Lett 2009; 9 (1): 491-5.

[101] Chan CK, Peng HL, Liu G, et al. High-performance lithium battery anodes using silicon nanowires. Nat Nanotechnol 2008; 3 (1): 31-5.

[102] Ruffo R, Hong SS, Chan CK, Huggins RA, Cui Y. Impedance analysis of silicon nanowire lithium ion battery anodes. J Phys Chem C 2009; 113 (26): 11390-8.

[103] Magasinski A, Dixon P, Hertzberg B, Kvit A, Ayala J, Yushin G. High-performance lithium-ion anodes using a hierarchical bottomup approach. Nat Mater 2010; 9 (4): 353-8.

[104] Magasinski A, Hertzberg B, Dixon P, Yushin G. 15th International Meeting on Lithium Batteries; July 2010; Montréal, Québec, Canada; 1010.

[105] Tarascon JM, Guyomard D. New electrolyte compositions stable over the $0-\mathrm{V}$ to $5-\mathrm{V}$ voltage range and compatible with the $\mathrm{Li}_{1+\mathrm{x}} \mathrm{Mn}_{2} \mathrm{O}_{4}$ Carbon Li-ion cells. Solid State Ionics 1994; 69 (3-4): 293-305.

[106] Ding MS, Xu K, Zhang SS, Amine K, Henriksen GL, Jow TR. Change of conductivity with salt content, solvent composition, and temperature for electrolytes of $\mathrm{LiPF}_{6}$ in ethylene carbonate-ethyl methyl carbonate. J Electrochem Soc 2001; 148 (10): A1196-204.
[107] Guyomard D, Tarascon JM. Li matal-free rechargeable $\mathrm{LiMn}_{2} \mathrm{O}_{4} /$ Carbon cells-Their understanding and optimization. J Electrochem Soc 1992; 139 (4): 937-48.

[108] Guyomard D, Tarascon JM. High-voltage stable liquid electrolytes for $\mathrm{Li}_{1+\mathrm{X}} \mathrm{Mn}_{2} \mathrm{O}_{4} /$ Carbon rocking- chair lithium batteries. J Power Sources 1995; 54 (1): 92-8.

[109] Oh B, Rempel J, Ofer D, Sriramulu S, Barnett B. 15th International Meeting on Lithium Batteries; July 2010; Montréal, Québec, Canada; 1010.

[110] Liu ZQ, Huang FQ, Yang JH, Wang BF, Sun JK. New lithium ion conductor, thio-LISICON lithium zirconium sulfide system. Solid State Ionics 2008; 179: 1714-6.

[111] Sakaebe H, Matsumoto H. N-methyl-N-propylpiperidinium bis (trifluoromethanesulfonyl) imide (PP13-TFSI)-novel electrolyte base for Li battery. Electrochem Commun 2003; 5: 594-8.

[112] Nakagawa H, Izuchi S, Kuwana K, Nukuda T, Aihara Y. Liquid and polymer gel electrolytes for lithium batteries composed of room-temperature molten salt doped by lithium salt. J Electrochem Soc 2003; 150: A695-700.

[113] Ishikawa M, Yamagata M. 15th International Meeting on Lithium Batteries; July 2010; Montréal, Québec, Canada 1010.

[114] Holzapfel M, Jost C, Nova'k P. Stable cycling of graphite in an ionic liquid based electrolyte. Chem Comm 2004; (18): 2098-9.

[115] Carlin RT, Fuller J, Hedenskoog M. Reversible lithium-graphite anodes in room-temperature chloroaluminate melts. J Electrochem Soc 1994; 141: L21-2.

[116] Fuller J, Osteryoung RA, Carlin RT. Rechargeable lithium and sodium anodes in chloroaluminate molten-salts containing thionyl chloride. J Electrochem Soc 1995; 142: 3632-6.

[117] Fuller J, Carlin RT, Osteryoung RA. The room temperaturei liquid 1-ethyl-3-methylimidazolium tetrafluoroborate: Electrochemical couples and physical properties. J Electrochem Soc 1997; 144: 3881-6.

[118] Katayama Y, Yukumoto M, Miura T. Electrochemical intercalation of lithium into graphite in room- temperature molten salt containing ethylene carbonate. Electrochem Solid-State Lett 2003; 6: A96-7.

[119] Holzapfel M, Jostb C, Novak P. Stable cycling of graphite in an ionic liquid based electrolyte. Chem Commun 2004; 2098-9.

[120] Appetecchi GB, Kim GT, Montanina M, et al. Ternary polymer electrolytes containing pyrrolidinium-based polymeric ionic liquids for lithium batteries. J Power Sources 2010; 195 (11): 3668-75.

[121] Lewandowski A, Swiderska-Mocek A. Ionic liquids as electrolytes for Li-ion batteries-An overview of electrochemical studies. J Power Sources 2009; 194 (2): 601-9.

[122] Stallworth PE, Fontanella JJ, Wintersgill MC, et al. NMR, DSC and high pressure electrical conductivity studies of liquid and hybrid electrolytes. J Power Sources 1999; 81: 739-47.

[123] Angell CA, Liu C, Sanchez E. Rubbery solid electrolytes with dominant cationic transport and high ambient conductivity. Nature 1993; 362 (6416): 137-9.

[124] Croce F, Appetecchi GB, Persi L, Scrosati B. Nanocomposite polymer electrolytes for lithium batteries. Nature 1998; 394 (6692): 456-8.

[125] MacFarlane DR, Huang JH, Forsyth M. Lithium-doped plastic crystal electrolytes exhibiting fast ion conduction for secondary batteries. Nature 1999; 402 (6763): 792-4.

[126] Zhang JW, Huang XB, Wei H, Fu JW, Huang YW, Tang XZ. Novel PEO-based solid composite polymer electrolytes with inorganic-organic hybrid polyphosphazene microspheres as fillers. J Appl Electrochem 2010; 40 (8): 1475-81.

[127] Alpen UV, Bell MF, Wichelhaus W. Ionic conductivity of $\mathrm{Li}_{14} \mathrm{Zn}\left(\mathrm{GeO}_{4}\right)_{4}$ (LISICON). Electrochim Acta 1978; 23: 1395-7.

[128] Hong HYP. Crystal structure and ionic conductivity of $\mathrm{Li}_{14} \mathrm{Zn}\left(\mathrm{GeO}_{4}\right)_{4}$ and other new $\mathrm{Li}^{+}$superionic conductors. Mat Res Bull 1978; 13: 117-24.

[129] Murayama M, Sonoyama N, Yamada A, Kanno R. Material design of new lithium ionic conductor, thio-LISICON, in the $\mathrm{Li}_{2} \mathrm{~S}-\mathrm{P}_{2} \mathrm{~S}_{5}$ system. Solid State Ionics 2004; 170 (3-4): 173-80.

[130] Kanno R, Hata T, Kawamoto Y, Irie M. Synthesis of a new lithium ionic conductor, thio-LISICON- lithium germanium sulfide system. Solid State Ionics 2000; 130 (1-2): 97-104.

[131] Hayashi A, Kitaura H, Ohtomo T, Hama S. Tatsumisago M, 15th International Meeting on Lithium Batteries; July 2010; Montréal, Québec, Canada; 1010. 
[132] Minami K, Mizuno F, Hayashi A, Tatsumisago M. Lithium ion conductivity of the $\mathrm{Li}_{2} \mathrm{~S}-\mathrm{P}_{2} \mathrm{~S}_{5}$ glass- based electrolytes prepared by the melt quenching method. Solid State Ionics 2007; 178 (11-12): 837-41.

[133] Trevey J, Jang JS, Jung YS, Stoldt CR, Lee SH. Glass-ceramic $\mathrm{Li}_{2} \mathrm{~S}-\mathrm{P}_{2} \mathrm{~S}_{5}$ electrolytes prepared by a single step ball billing process and their application for all-solid-state lithium-ion batteries. Electrochem Commun 2009; 11 (9): 1830-3.

[134] Mizuno F, Hama S, Hayashi A, Tadanaga K, Minami T, Tatsumisago M. All solid-state lithium secondary batteries using high lithium ion conducting $\mathrm{Li}_{2} \mathrm{~S}-\mathrm{P}_{2} \mathrm{~S}_{5}$ glass-ceramics. Chem Lett 2002; (12): 1244-5.

[135] Hashimoto Y, Machida N, Shigematsu T. Preparation of $\mathrm{Li}_{4.4} \mathrm{Ge}_{\mathrm{x}} \mathrm{Si}_{1-\mathrm{x}}$ alloys by mechanical milling process and their properties as anode materials in all-solid-state lithium batteries. Solid State Ionics 2004; 175 (1-4): 177-80.

[136] Takada K, Inada T, Kajiyama A, et al. Solid state batteries with sulfide-based solid electrolytes. Solid State Ionics 2004; 172 (1-4): 25-30.

[137] Zhang SS. A review on the separators of liquid electrolyte Li-ion batteries. J Power Sources 2007; 164 (1): 351-64.

[138] Kim SS, Lim GBA, Alwattari AA, Wang YF, Lloyd DR. Microporous membrane formation via thermally-induced phaseseparation. 5. Effect of diluent mobility and crystallization on the structure of isotactic polypropylene membranes. J Membr Sci 1991; 64 (1-2): 41-53.

[139] Vadalia HC, Lee HK, Myerson AS, Levon K. Thermally-induced phase-separation in ternary crystallizable polymer-solutions. J Membr Sci 1994; 89 (1-2): 37-50.

[140] Matsuyama H, Yuasa M, Kitamura Y, Teramoto M, Lloyd DR. Structure control of anisotropic and asymmetric polypropylene membrane prepared by thermally induced phase separation. J Membr Sci 2000; 179 (1-2): 91-100.

[141] Venugopal G, Moore J, Howard J, Pendalwar S. Characterization of microporous separators for lithium-ion batteries. J Power Sources 1999; 77 (1): 34-41.

[142] Arora P, Zhang ZM. Battery separators. Chem Rev 2004; 104 (10): 4419-62.

[143] http://www.celgard.com/.

[144] Chung YS, Yoo SH, Kim CK. Enhancement of meltdown temperature of the polyethylene lithium- ion battery separator via surface coating with polymers having high thermal resistance. Ind Eng Chem Res 2009; 48 (9): 4346-51.

[145] Yoo SH, Kim CK. Enhancement of the meltdown temperature of a lithium ion battery separator via a nanocomposite coating. Ind Eng Chem Res 2009; 48 (22): 9936-41.

[146] Cho TH, Tanaka M, Onishi H, et al. Silica-composite nonwoven separators for lithium-ion battery: Development and characterization. J Electrochem Soc 2008; 155 (9): A699-703.

[147] Prosini PP, Villano P, Carewska M. A novel intrinsically porous separator for self-standing lithium- ion batteries. Electrochim Acta 2002; 48 (3): 227-33.

[148] Augustin S, Hennige V, Horpel G, Hying C. Ceramic but flexible: new ceramic membrane foils for fuel cells and batteries. Desalination 2002; 146 (1-3): 23-8.

[149] Hennige V, Hying C, Hörpel G. Pyrogenic oxidic powder, production thereof and use thereof in a separator for electrochemical cell. US7759009B2, July 20, 2010.

[150] Kim M, Shon JY, Nho YC, Lee TW, Park JH. Positive effects of ebeam irradiation in inorganic particle based separators for lithiumion battery. J Electrochem Soc 2010; 157 (1): A31-4. 